\title{
Effect of cow manure on growth and bioactive components of Gynura pseudochina (Asteraceae)
}

\author{
Inek gübresinin Gynura pseudochina (Asteraceae) büyümesine ve biyoaktif bileşenlerine etkisi

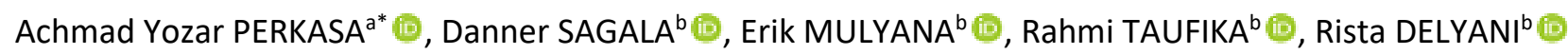 \\ a Department of Field Crops, Faculty Agriculture, Ankara University, 06120, Ankara, Turkey \\ ${ }^{\mathrm{b}}$ Department Agronomy and Horticulture, Graduate School Faculty of Agriculture, Bogor Agricultural University, Bogor, Indonesia
}

\section{Article Info}

(C)2018 Ali Nihat Gökyiğit Botanical Garden Application and Research Center of Artvin Çoruh University.

*Corresponding author:

e-mail: perkasa@ankara.edu.tr

ORCID: 0000-0002-8327-1599

\section{Article history}

Received: May 17, 2019

Received in revised form: July 16, 2019

Accepted: August 07, 2019

Available online: August 29, 2019

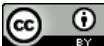

This is an Open Access article under the CC BY license (http://creativecommons.org/licenses /by/4.0/).

\section{Keywords:}

Cow manure fertilizer, bioactive compound, dose, Gynura pseudochina, physiology components.

Anahtar kelimeler:

Inek gübresi, biyoaktif bileşik, doz, Gynura pseudochina, fizyoloji bileşenleri.

\begin{abstract}
The objective of this study is to determine the effect of different amounts of cow manure on growth and leaf content of Gynura pseudochina, a medicinal plant. The experiment was arranged in a randomized block design. The first factor was the dose of cow manure with three levels $(0 \mathrm{~g}$ polybag1 (control), $500 \mathrm{~g}$ polybag- 1 and $1000 \mathrm{~g}$ of polybag-1). Each experiment was repeated as 4 times. The data were analyzed with variance analysis by SAS 9.1 .3 programme, significant differences at $5 \%$ were also analyzed by Duncan's Multiple Range Test. As a result of the studies, it was observed that the fertilization treatment with different doses of cow manure did not provide a significant difference in growth after 3 weeks after planting, but the leaf width was the highest after 4 weeks. In this study, it was determined that cow feces and fertilization did not increase the content of bioactive compounds of the leaf of Gynura pseudochina and the growth of canopies and tubers. The high rate of caterpillar infestations that occurred two weeks after planting disrupted the growth of Gynura pseudochina and the production of bioactive compounds. The results of the study clearly showed that cow manure did not properly increase the growth of canopies, tubers and the content of bioactive compounds of Gynura pseudochina.
\end{abstract}

\section{öz}

Bu araştırmanın amacı, tıbbi bir bitki olan Gynura pseudochina'nın farklı miktarlarda inek gübresiyle yetiştirilmesi ile büyümesine ve yaprak bileşenlerine olan etkisinin ortaya konulmasıdır. Çalışmalar rastgele bir blok tasarımında oluşturulmuştur. Illk faktör, üç aşamada farklı inek gübresi dozu $(0 \mathrm{~g}$ polybag-1 (kontrol), $500 \mathrm{~g}$ polybag-1 ve $1000 \mathrm{~g}$ polybag-1) ile oluşturulmuştur. Çalışma dört defa tekrarlanmıştır. Veriler, SAS 9.1.3 programında, varyans analizi ile analiz edilmiş, \% 5 düzeyinde önemli faklııı gözlenenler Duncan'ın Multiple Range Testi ile de analiz edilmiştir. Çalışmalar sonucunda, inek gübresinin farklı dozları ile yapılan gübreleme tedavisinin bitkiler dikildikten 3 hafta sonra büyümede önemli bir farklılık sağlamadığı ama 4 hafta sonra yaprak genişliğinin en fazla oranda olduğu gözlenmiştir. Bu çalışmada kullanılan inek dışkısı ile gübrelemenin Gynura pseudochina'nın yaprağının biyoaktif bileşiklerinin içeriğini ve kanopilerin, yumrularının büyümesini arttırmadığı belirlenmiştir. Bitkilerin ekiminden iki hafta sonra gerçekleşen yüksek oranda tırtıl istilası Gynura pseudochina'nın büyümesini ve biyoaktif bileşiklerinin üretimini bozmuştur. Çalışma sonuçları açıkça göstermiştir ki inek gübresiyle gübrelemenin kanopilerin, yumruların büyümesini ve Gynura pseudochina'nın biyoaktif bileşiklerinin içeriğini düzgün şekilde arttırmamıştır.

\section{Citation:}

To cite this article: Perkasa AY, Sagala D, Mulyana E, Taufika R, Delyani R (2019). Effect of cow manure on growth and bioactive components of Gynura pseudochina (Asteraceae). Turk J Biod 2(2): 39-47.

\section{INTRODUCTION}

Dewa leaf (Gynura pseudochina (L.) DC.) is a potentially medicinal plant widely studied for the contents of their metabolites. Gynura procumbens is widely used to reduce blood sugar levels, as a skin remedy, cure migrein, hepatitis $B$, reduce heat, eliminate swelling, anti-tumor, anti-cancer, to larvacide (Gati \& Purnamaningsih, 1994; Suharmiati \& Maryani 2003; Fuadzy \& Marina, 2012. Ratnaningsih et al., 1985). Research on wistar rats, dewa leaf can accelerate coagulation time and be able to function as an antiseptic drug (Novayanti, 2012). Windono and Jenie (2012) study states that the cytotoxic power of leaves on the leaves of dewa leaf is stronger 
than in the tubers where the cytotoxic fraction contains palmitic acid.

Fertilization can contribute to the nutrient content of the soil. Fertilizing with organic fertilizers such as manure has been widely studied in medicinal plants. The research on rhino ginger states that the treatment of 45 tons $/ \mathrm{ha}^{-1}$ of cow manure gives better growth and rhizome production value than a dose of 30 tons ha- ${ }^{-1}, 15$ tons ha ${ }^{-1}, 0$ tons ha ${ }^{-1}$ (Santoso, 1997). Hernani's (2008) study on Java chili also stated that the treatment of cow manure can improve the vegetative growth of plants where the optimum dose for best growth is $662 \mathrm{~g}$ per $10 \mathrm{~kg}$ of soil. The treatment of cow manure with a dose of $750 \mathrm{~g}$ per $10 \mathrm{~kg}$ of soil can reduce vegetative growth.

The response of plants in response to differences in nutrients received may differ from one another, especially in the production of bioactive compounds. Therefore, this research aims to determine the growth and quantification of compounds of dewa leaf with various doses of cow manure.

\section{MATERIAL AND METHOD}

\subsection{Material}

The materials used were seed of dewa leaf (Gynura pseudochina), husk charcoal, cows manure, topsoil, solution extractors acetris (a mixture of $85 \%$ acetone), and $15 \%$ Tris stock buffer ( $1 \%$ Tris, $\mathrm{pH} 8$ with $\mathrm{HCl}$ ). The tools used for experiment in the form of polybags size of $8 \mathrm{~kg}$, tweezers/razor, scissors, analytical balance, plastic bags, paper envelopes, and agricultural tools such as hoes, chopper, sickle, shears, drill, buckets, and tools in laboratory used for analysis chlorophyll (the pit with a diameter of approximately $1 \mathrm{~cm}$, porcelain mortar, micro tubes, test tubes, pipettes micro centrifuge apparatus, UV-Visible spectrophotometer, cuvet).

\subsection{Method}

The experiment was conducted on February 20 until May 30, 2014 at the Biofarmaka experiment station $06^{\circ} 33.4^{\prime} 53^{\prime \prime} S$ and $106^{\circ} 43.1^{\prime} 43^{\prime \prime} \mathrm{E}$, Bogor Agricultural University. Analysis chlorophyll conducted in Plant Molecular Biology Laboratory 2 and post-harvest handling at the Post Harvest Laboratory, Department of Agronomy and Horticulture, Faculty of Agriculture, Bogor Agricultural University.

Experimental design: This study used a randomized block design with treatment doses of cow manure, namely: Control $=$ without the addition of cow manure; S500 = addition of $500 \mathrm{~g}$ of cow manure; $\mathrm{S} 1000=$ addition of $1000 \mathrm{~g}$ of cow manure. The medium used is a mixture of soil, rice husk and fertilizer dose of $250 \mathrm{~g}$ cow manure. Husk is added in the mix of media so that the media weight to $8 \mathrm{~kg}$. Treatment S500 and S1000 repeated 4 times and the control is repeated 6 times.

\section{Field Trial}

The Observations included:

1. The length of leaf $(\mathrm{cm})$; measured starting from the leaf base to the tip of the leaf

2. The width of the leaves of plants $(\mathrm{cm})$; measured from both sides of the widest leaves (observed in the widest leaves)

3. Plant height $(\mathrm{cm})$; measured from ground level to the highest growing point

4. The number of leaves (pieces); calculated from the number of leaves leaf-shaped perfect every week

5 . The number of tillers; done by counting the number of seedlings that emerged

6. The weight of the wet and dry bulb (g) that is kiln dried for 3 days at a temperature of $60^{\circ} \mathrm{C}$.

7. Measurement of chlorophyll A, chlorophyll B, anthocyanins and carotenoids

\section{Laboratory Experiments}

Observations were made on chlorophyll, anthocyanins and carotenoids.

The method used is:

1. Samples of leaves that have been used are perfectly formed and located at the center position. Samples leaves cleaned of dirty by using a rag

2. Leaves weighed as much as $0.02 \mathrm{~g}$, then immediately crushed with a porcelain mortar with $2 \mathrm{ml}$ acetris added and incorporated into the micro tube $2 \mathrm{ml}$

3. Samples in micro tube centrifuged

4. The supernatant was taken $1 \mathrm{ml}$ with a micro pipette, and then put into a test tube containing $3 \mathrm{ml}$ acetris bringing the total to $4 \mathrm{ml}$ solution (dilution factor is $4 \mathrm{ml}$ / $1 \mathrm{ml}$ of the supernatant $=4$ )

5. To reduce evaporation holes test tubes covered with marbles

6. The absorbance measurement is done by inserting the sample into the cuvet and measured using a UV-Visible spectrophotometer at wavelengths of $663,647,537$, and $470 \mathrm{~nm}$

7. The measurement results incorporated into the calculation formula Sims and Gamon (2002) 


\section{RESULTS}

The treatment of cow manure doses in general did not give a significant difference in the growth and production of dewa leaf except for plant height at 3 weeks after transplanting (WAT) and widest leaf width at 4 WAT (Table 1). Therefore, the data obtained in this experiment will be presented in the form of tabulations to see the trend of growth and yield of the leaves of dewa leaf by treating doses of cow manure.

The general condition of the location and implementation of the experiment has been well designed, but caterpillar pests (Nyctemera sp.) attack since the plant is 2 WAT. The control of caterpillar pests is carried out physically/mechanically which is killing the caterpillar by hand. Pests continue to occur until the plants are 8 WAT and the plants are harvested even though they are not in accordance with the planned harvest time (Figure 1). Another condition is that experiments are arranged in the shade condition so the sunlight does not illuminate some experimental units.

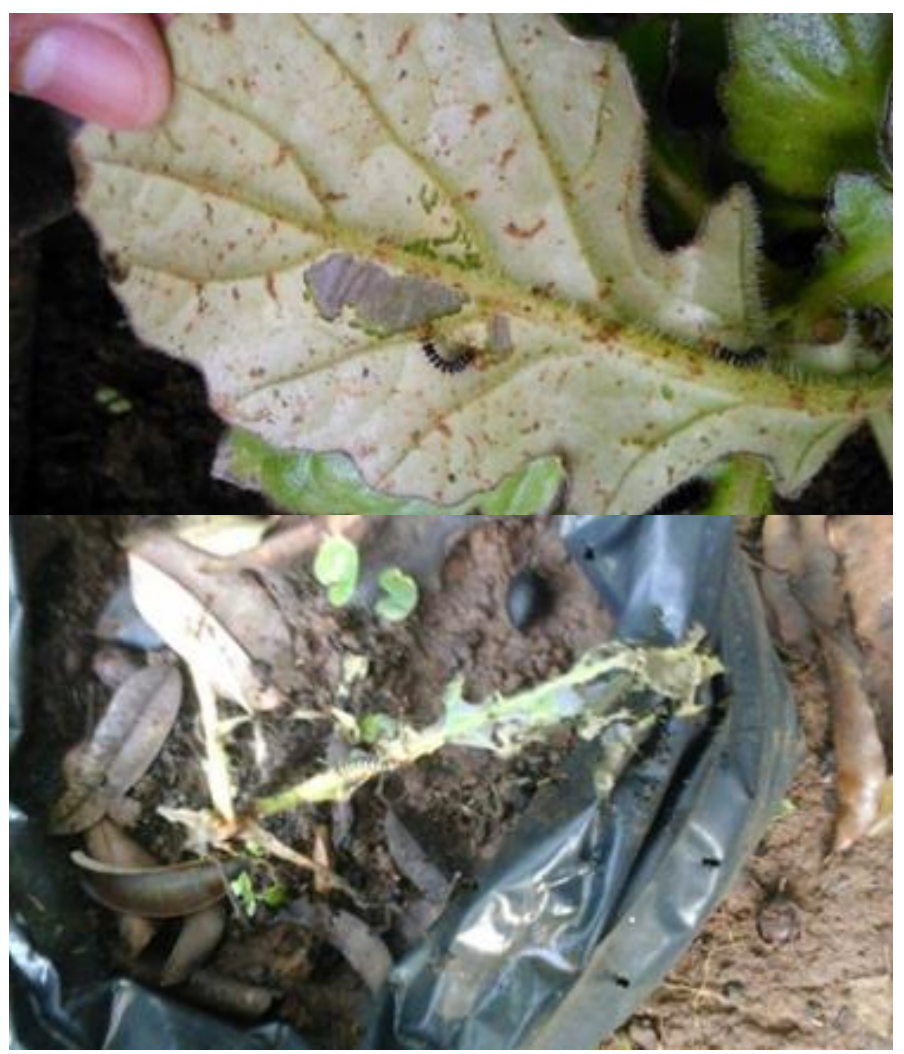

Figure 1. Caterpillar attack on 1 WAT and 8 WAT

Table 1. Recapitulation of variance parameters of growth and production of dewa leaf

\begin{tabular}{|c|c|c|c|c|c|c|c|c|}
\hline Parameters & 1 WAT & 2 WAT & 3 WAT & 4 WAT & 5 WAT & 6 WAT & 7 WAT & 8 WAT \\
\hline Plant height & ns & ns & $*$ & $\mathrm{~ns}$ & ns & ns & ns & \\
\hline Diameter heading & ns & ns & ns & ns & ns & ns & ns & \\
\hline Number of leaves & ns & ns & ns & ns & ns & ns & ns & \\
\hline The length of leaf & ns & ns & ns & ns & ns & ns & ns & \\
\hline The width of leaf & ns & ns & ns & $*$ & ns & ns & ns & \\
\hline tillers & & & & & ns & ns & ns & \\
\hline Weight of wet bulb & & & & & & & & ns \\
\hline Weight of dry bulb & & & & & & & & ns \\
\hline Chlorophyll A & & & & & & & & ns \\
\hline Chlorophyll B & & & & & & & & ns \\
\hline Carotenoid & & & & & & & & ns \\
\hline Anthocyanin & & & & & & & & ns \\
\hline
\end{tabular}

Remarks: ${ }^{*}=$ Significantly different at the level of $\alpha=5 \%, \mathrm{~ns}=$ not significant, CoD $=$ coefficient of diversity, WAT = weeks after treatment. 
The increase in the height of the dewa leaf plant occurs with the age of the plant. The height increment for control, S500, S1000 are 1.47, 1.72; and $1.93 \mathrm{~cm}$ respectively. The biggest increase in height was in the treatment of S500 from 6 WAT to 7 WAT, but at the S500 there was also a high increase which was negative, ie from 5 WAT to 6 WAT (Table 2). The use of cow manure with a dose of $500 \mathrm{~g}$ of plant ${ }^{-1}$ tended to increase plant height except at 6 WAT and if added to $1000 \mathrm{~g}$ of plant ${ }^{-1}$, the increase in height was not as large as the treatment of $500 \mathrm{~g}$ of plant ${ }^{-1}$ (Figure 2).

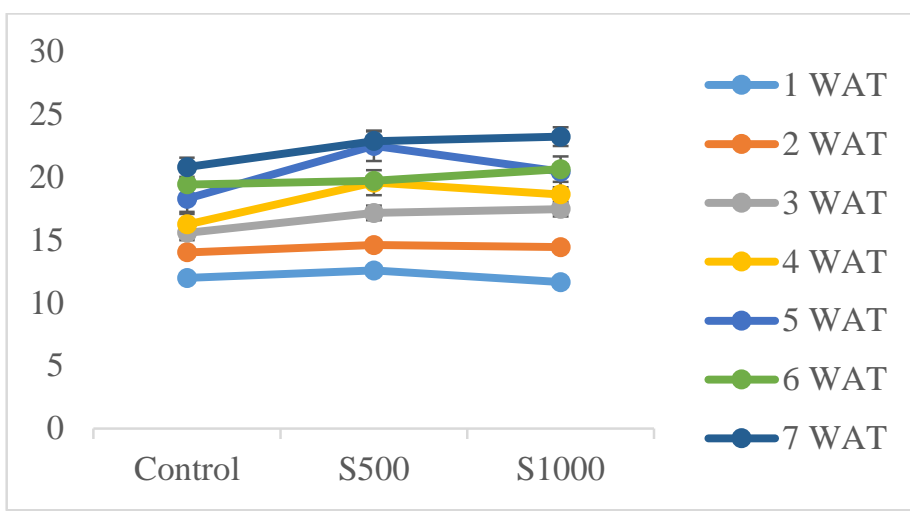

Figure 2. Graph of the height of the dewa leaf with the treatment of cow manure doses

Table 2. Effect of cow manure dosage on the height of the dewa leaf plant

\begin{tabular}{llllllll}
\hline Treatment & 1 WAT & 2 WAT & 3 WAT & 4 WAT & 5 WAT & 6 WAT & 7 WAT \\
\hline Control & 11.98 & 14.02 & 15.58 & 16.24 & 18.28 & 19.43 & 20.80 \\
S500 & 12.57 & 14.60 & 17.15 & 19.57 & 22.50 & 19.70 & 22.88 \\
S1000 & 11.65 & 14.43 & 17.47 & 18.63 & 20.43 & 20.63 & 23.23 \\
\hline F Test & $0.451 \mathrm{~ns}$ & $0.371 \mathrm{~ns}$ & $0.029 *$ & $0.053 \mathrm{~ns}$ & $0.113 \mathrm{~ns}$ & $0.416 \mathrm{~ns}$ & $0.428 \mathrm{~ns}$ \\
CoD $(\%)$ & 5.64 & 5.36 & 6.20 & 9.45 & 14.00 & 18.01 & 17.28 \\
\hline
\end{tabular}

Remarks: Figures on the same column followed by the same letter show no significantly different results based DMRT at the level of $\alpha=5 \% .{ }^{*}=$ Significantly different at the level of $\alpha=5 \%$, ns = not significant, $\mathrm{CoD}=$ coefficient of diversity, WAT = weeks after treatment.

The increase in canopy diameter of the dewa leaf occurred with the age of the plant. The average increase in crown diameter for controls, S500, S1000 are 1.97, 1.72 , and $2.49 \mathrm{~cm}$ respectively. The biggest increase in canopy diameter was in the treatment of 5500 from 6 WAT to 7 WAT, but at the 5500 also showed a negative increase in canopy diameter i.e. from 5 WAT to 6 WAT (Table 3). The use of cow manure with a dose of $500 \mathrm{~g}$ of plant $^{-1}$ tended to increase plant canopy diameter except at 1,6 , and 7 WAT and if added to $1000 \mathrm{~g}$ of plant $^{-1}$, the addition of canopy diameter 4 and 5 WAT exceeded the diameter of $500 \mathrm{~g}$ of plant ${ }^{-1}$ (Figure 3).

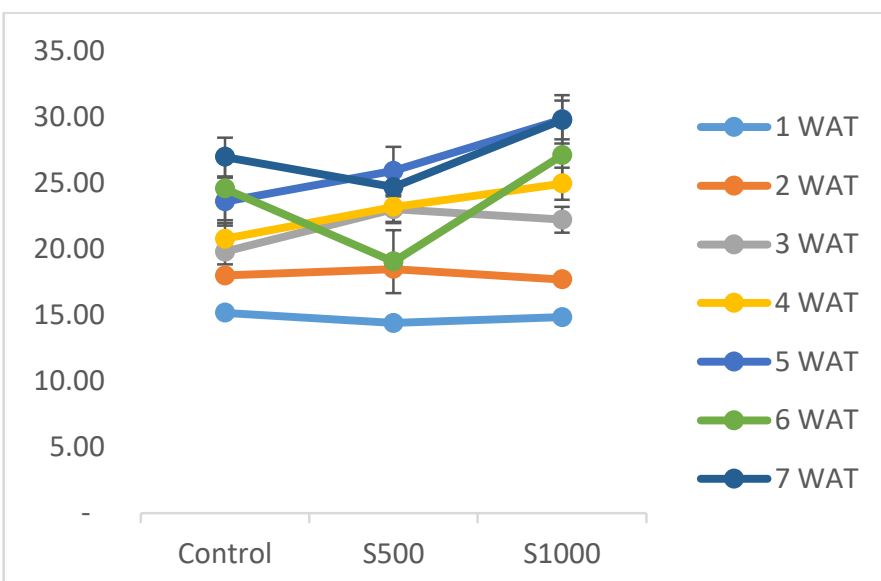

Figure 3. Graph of the canopy leaf diameter with the treatment of cow manure doses

Table 3. Effect of cow manure dosage on diameter of canopy leaves of dewa leaf

\begin{tabular}{llllllll}
\hline Treatment & 1 WAT & 2 WAT & 3 WAT & 4 WAT & 5 WAT & 6 WAT & 7 WAT \\
\hline Control & 15.15 & 17.98 & 19.78 & 20.75 & 23.58 & 24.56 & 26.96 \\
S500 & 14.38 & 18.47 & 23.00 & 23.17 & 25.90 & 19.03 & 24.67 \\
S1000 & 14.83 & 17.68 & 22.20 & 24.93 & 29.80 & 27.08 & 29.75 \\
\hline F Test & $1.00 \mathrm{~ns}$ & $0.96 \mathrm{~ns}$ & $0.07 \mathrm{~ns}$ & $0.09 \mathrm{~ns}$ & $0.06 \mathrm{~ns}$ & $0.69 \mathrm{~ns}$ & $0.87 \mathrm{~ns}$ \\
CoD (\%) & 22.18 & 13.59 & 7.08 & 10.37 & 9.81 & 35.67 & 30.39 \\
\hline
\end{tabular}

Remarks: Figures on the same column followed by the same letter show no significantly different results based DMRT at the level of $\alpha=5 \% .{ }^{*}=$ Significantly different at the level of $\alpha=5 \%$, ns = not significant, CoD = coefficient of diversity, WAT = weeks after treatment. 
The increase in the number of leaves of the dewa leaf occurs with the age of the plant. The average number of leaves for control, S500, are $0.78,1.13$ and $0.58 \mathrm{~cm}$, respectively. The largest number of leaf growth was in the treatment of S500 from 1 WAT to 2 WAT, but in the S500 and controls it was also seen that the number of leaves was negative which was from 4 WAT to 5 WAT (Table 4). The use of cow manure with a dose of $500 \mathrm{~g}$ of plant ${ }^{-1}$ tended to increase the number of leaf plants only at 1 , and 4 WAT and if added to $1000 \mathrm{~g}$ of plant ${ }^{-1}$ the number of leaves did not exceed the number of leaves in the treatment of $500 \mathrm{~g}$ of plant $^{-1}$ (Figure 4).

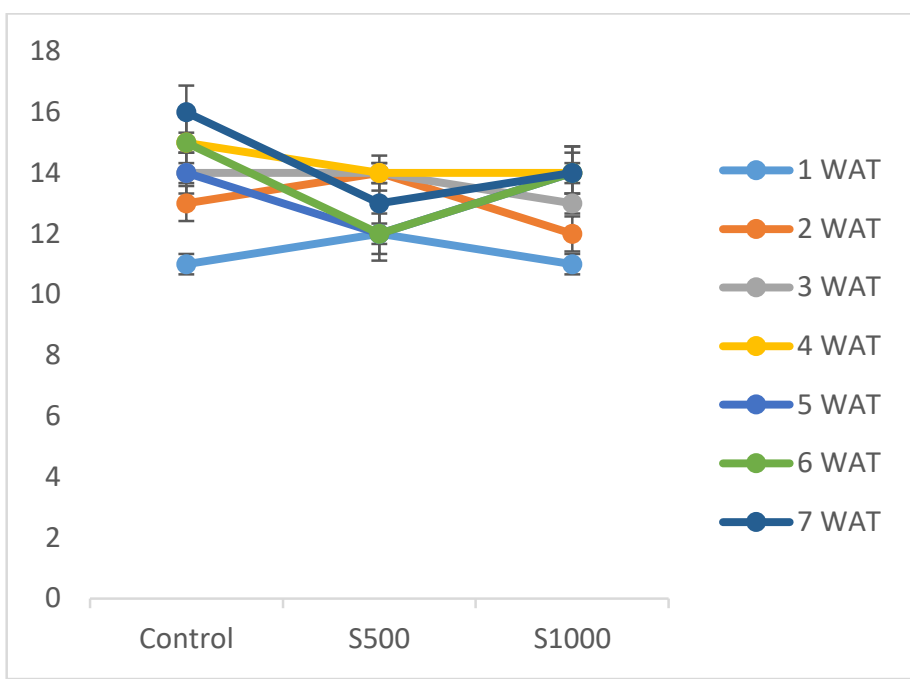

Figure 4. Graph of the number of leaves of dewa leaf by treating doses of cow manure

Table 4 Effect of cow manure dosage on the number of leaves of dewa leaf

\begin{tabular}{llllllll}
\hline Treatment & 1 WAT & 2 WAT & 3 WAT & 4 WAT & 5 WAT & 6 WAT & 7 WAT \\
\hline Control & 11 & 13 & 14 & 15 & 14 & 15 & 16 \\
S500 & 12 & 14 & 14 & 14 & 12 & 12 & 13 \\
S1000 & 11 & 12 & 13 & 14 & 14 & 14 & 14 \\
\hline F Test & $0.18 \mathrm{~ns}$ & $0.24 \mathrm{~ns}$ & $0.46 \mathrm{~ns}$ & $0.57 \mathrm{~ns}$ & $0.22 \mathrm{~ns}$ & $0.18 \mathrm{~ns}$ & $0.42 \mathrm{~ns}$ \\
CoD (\%) & 9.52 & 14.06 & 19.78 & 23.30 & 14.76 & 17.53 & 27.72 \\
\hline
\end{tabular}

Remarks: Figures on the same column followed by the same letter show no significantly different results based DMRT at the level of $\alpha=5 \%$. ${ }^{*}=$ Significantly different at the level of $\alpha=5 \%, \mathrm{~ns}=$ not significant, $\mathrm{CoD}=$ coefficient of diversity, WAT = weeks after treatment.

The length of the leaves of dewa leaf occurs with the age of the plant. The average length of leaves for the control, $\mathrm{S} 500, \mathrm{~S} 1000$ are $0.63,0.92$ and $0.93 \mathrm{~cm}$, respectively. The biggest leaf length increase was in the control treatment from 3 WAT to 4 WAT, but in control 2 WAT to 3 WAT, S500 and S1000 from 5 WAT to 6 WAT also seen leaf length increments were negative (Table 5). The use of cow manure with a dose of $500 \mathrm{~g}$ of plant ${ }^{-1}$ tended to increase the length of plant leaves except at 1 and 2 WAT and if added to $1000 \mathrm{~g}$ of plant ${ }^{-1}$ leaf length increase exceeded the leaf length in the treatment of $500 \mathrm{~g}$ of plant $^{-1}$ except 2, 5 and 6 WAT (Figure 5).

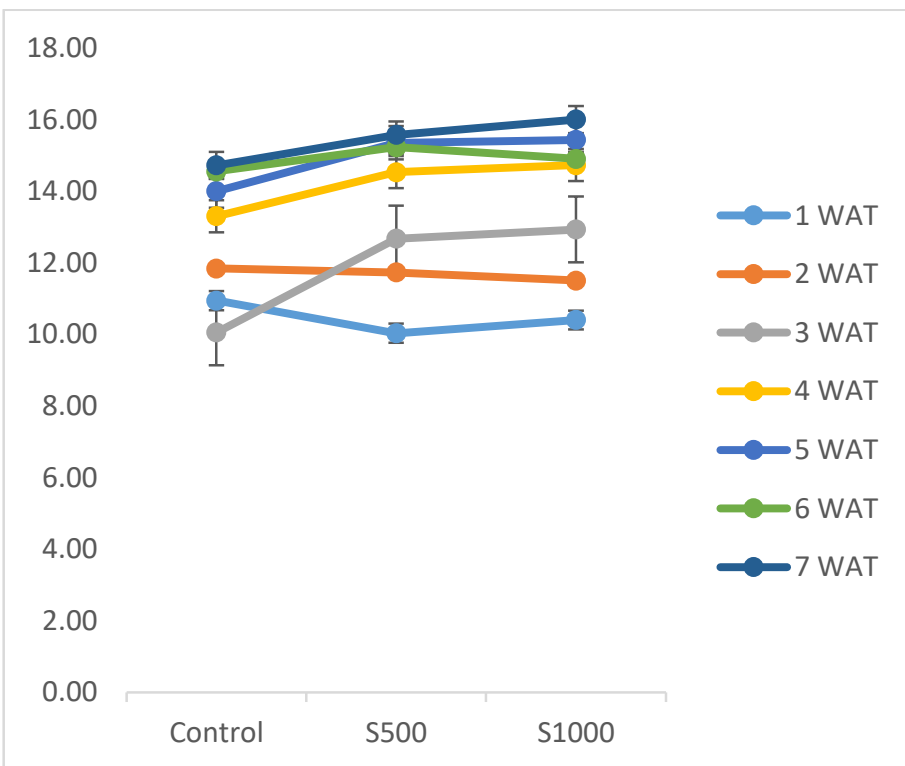

Figure 5. Graph of the widest leaves width of the dewa leaf with the treatment of cow manure doses 
Table 5. Effect of cow manure doses on the length of the widest leaves of the dewa leaf

\begin{tabular}{llllllll}
\hline Treatment & 1 WAT & 2 WAT & 3 WAT & 4 WAT & 5 WAT & 6 WAT & 7 WAT \\
\hline Control & 10.94 & 11.84 & 10.05 & 13.30 & 14.00 & 14.55 & 14.72 \\
S500 & 10.03 & 11.73 & 12.67 & 14.53 & 15.35 & 15.23 & 15.57 \\
S1000 & 10.40 & 11.50 & 12.93 & 14.73 & 15.43 & 14.90 & 16.00 \\
\hline F Test & $0.08 \mathrm{~ns}$ & $0.52 \mathrm{~ns}$ & $0.48 \mathrm{~ns}$ & $0.15 \mathrm{~ns}$ & $0.59 \mathrm{~ns}$ & $0.71 \mathrm{~ns}$ & $0.32 \mathrm{~ns}$ \\
CoD $(\%)$ & 6.15 & 6.93 & 28.00 & 7.18 & 14.13 & 16.77 & 17.69 \\
\hline
\end{tabular}

Remarks: Figures on the same column followed by the same letter show no significantly different results based DMRT at the level of $\alpha=5 \% .{ }^{*}=$ Significantly different at the level of $\alpha=5 \%$, ns = not significant, $\mathrm{COD}=$ coefficient of diversity, WAT = weeks after treatment.

The width of the leaves of dewa leaf occurs with the age of the plant. The average increase in leaf width for controls, S500, S1000 are respectively $0.27,0.36$ and 0.44 $\mathrm{cm}$. The largest increase in leaf width was in the treatment of S500 from 6 WAT to 7 WAT, but at S500 from 4 WAT to 5 WAT and 5 WAT to 6 WAT also seen a negative leaf width increase (Table 6). The use of cow manure with a dose of $500 \mathrm{~g}$ of plant ${ }^{-1}$ tended to increase the width of plant leaves except at 1 and 6 WAT and if added to 1000 $\mathrm{g}$ of plant ${ }^{-1}$ leaf width increase exceeded the leaf width on treatment g plant ${ }^{-1}$ except 2, and 4 WAT (Figure 6) .

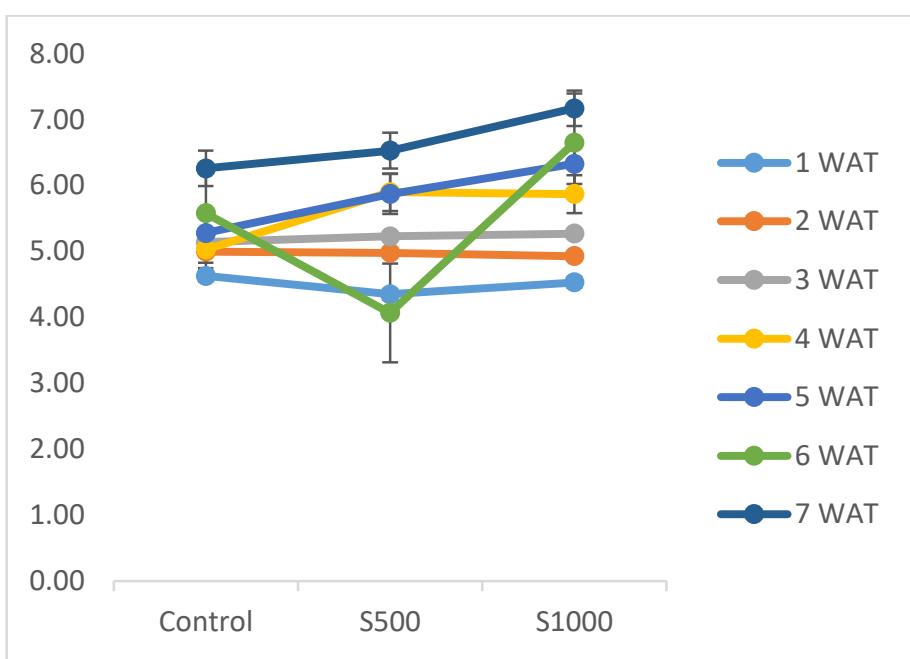

Figure 6. Graph of the widest leaves width of the dewa leaf with the treatment of cow manure doses

Table 6. Effect of cow manure dosage on the width of the widest leaves of the dewa leaf

\begin{tabular}{llllllll}
\hline Treatment & 1 WAT & 2 WAT & 3 WAT & 4 WAT & 5 WAT & 6 WAT & 7 WAT \\
\hline Control & 4.63 & 5.00 & 5.14 & $5.03 \mathrm{~b}$ & 5.28 & 5.58 & 6.26 \\
S500 & 4.35 & 4.98 & 5.23 & $5.90 \mathrm{a}$ & 5.87 & 4.07 & 6.53 \\
S1000 & 4.53 & 4.93 & 5.27 & $5.87 \mathrm{a}$ & 6.33 & 6.65 & 7.17 \\
\hline F Test & $0.13 \mathrm{~ns}$ & $0.75 \mathrm{~ns}$ & $0.77 \mathrm{~ns}$ & $0.02^{*}$ & $0.20 \mathrm{~ns}$ & $0.52 \mathrm{~ns}$ & $0.39 \mathrm{~ns}$ \\
CoD $(\%)$ & 4.50 & 2.78 & 5.62 & 7.29 & 12.67 & 35.14 & 19.86 \\
\hline
\end{tabular}

Remarks: Figures on the same column followed by the same letter show no significantly different results based DMRT at the level of $\alpha=5 \% .{ }^{*}=$ Significantly different at the level of $\alpha=5 \%$, ns = not significant, CoD = coefficient of diversity, WAT = weeks after treatment.

The increase in the number of saplings of the dewa leaf occurs with the age of the plant. The average number of tillers for the control, S500, S1000 are 1.68, 1.70 and 208 $\mathrm{cm}$, respectively. The biggest increase in the number of tillers was in treatment $\$ 1000$ from 6 WAT to 7 WAT (Table 7). The use of cow manure with a dose of $500 \mathrm{~g}$ of plant $^{-1}$ tended not to increase the number of tillers and if added to $1000 \mathrm{~g}$ of plant $^{-1}$, the increase in number of tillers exceeded the number of tillers in the treatment of $500 \mathrm{~g}$ of plant ${ }^{-1}$ (Figure 7).

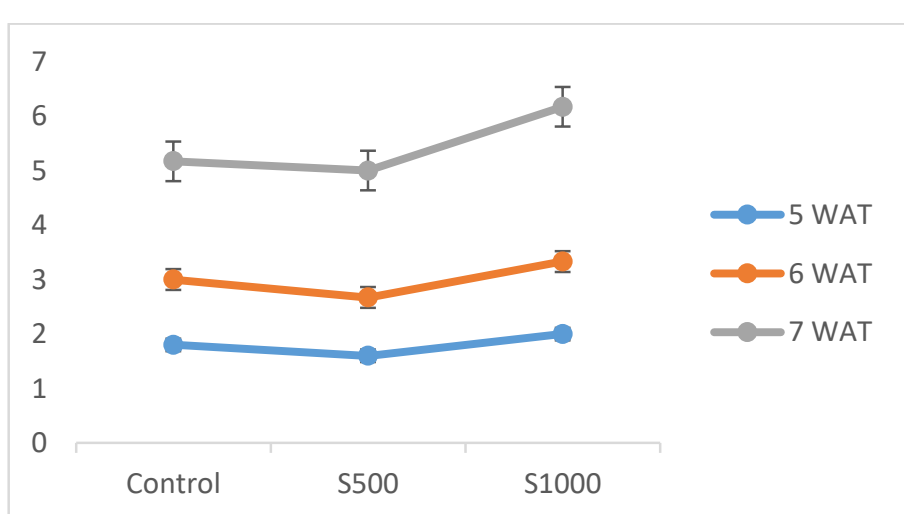

Figure 7. Graph of the number of leaves of gods with doses of cow manure 
Table 7. Effect of cow manure dosage on the number of dewa leaf

\begin{tabular}{llll}
\hline Treatment & 5 WAT & 6 WAT & 7 WAT \\
\hline Control & 1.8 & 3.00 & 5.17 \\
S500 & 1.6 & 2.67 & 5.00 \\
S1000 & 2.0 & 3.33 & 6.17 \\
\hline F Test & $0.86 \mathrm{~ns}$ & $0.81 \mathrm{~ns}$ & $0.87 \mathrm{~ns}$ \\
KK (\%) & $22.86^{\wedge}$ & $33.33^{\wedge}$ & $31.84^{\wedge}$ \\
\hline
\end{tabular}

Remarks: Figures on the same column followed by the same letter show no significantly different results based DMRT at the level of $\alpha=$ $5 \%$. ${ }^{*}=$ Significantly different at the level of $\alpha=5 \%$, ns = not significant, $\mathrm{COD}=$ coefficient of diversity, WAT $=$ weeks after treatment ${ }^{\wedge}=$ transformation $\sqrt{(\mathrm{x}+2)}$.

Increasing doses of cow manure from $0 \mathrm{~g}$ of plant ${ }^{-1}$ (control) to $500 \mathrm{~g}$ of plant $^{-1}$ was not followed by an increase in wet weight and dry weight of tubers, but a decrease in wet weight and dry weight of tuber. The addition of cow manure doses to $1000 \mathrm{~g}$ of plant ${ }^{-1}$ increased the wet weight and dry weight of the tuber but did not exceed the wet weight and dry weight of the control treatment (Table 8 \& Figure 8).

Table 8. Effect of cow manure dosage on wet weight and dry weight of dewa leaf plant

\begin{tabular}{lll}
\hline Treatment & Weight of Wet $(\mathrm{g})$ & Weight of Dry $(\mathrm{g})$ \\
\hline Control & 13.90 & 2.48 \\
S500 & 9.71 & 1.82 \\
S1000 & 12.94 & 2.30 \\
\hline F Test & $0.62 \mathrm{~ns}$ & $0.70 \mathrm{~ns}$ \\
CoD (\%) & 29.27 & 34.46 \\
\hline
\end{tabular}

Remarks: Figures on the same column followed by the same letter show no significantly different results based DMRT at the level of $\alpha=$ $5 \%{ }^{*}=$ Significantly different at the level of $\alpha=5 \%$, ns = not significant, $\mathrm{COD}=$ coefficient of diversity, WAT $=$ weeks after treatment.

The highest content of chlorophyll a, chlorophyll b, carotenoid and anthocyanin are found in treatment S1000, S1000, S500 and S1000 respectively. The content of chlorophyll a, chlorophyll b and anthocyanin tends to increase with increasing doses of cow manure. Carotenoid content increases at $\mathrm{S} 500$ dose and decreases at S1000 dose (Table 9).

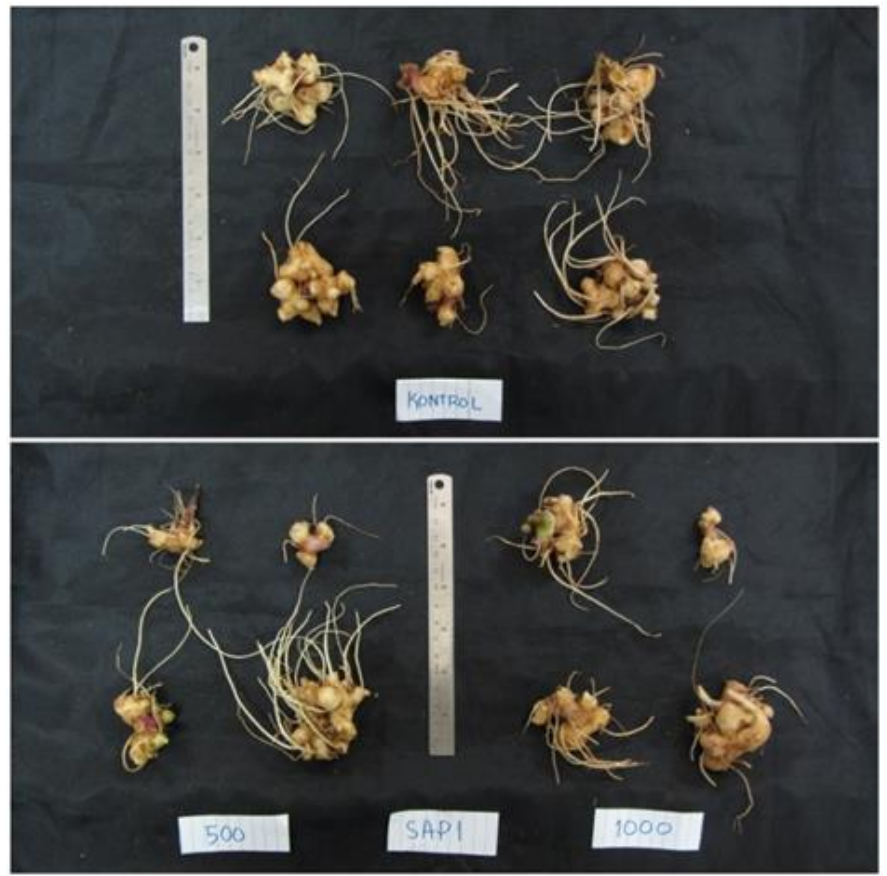

Figure 8. Bulb performance in various treatments of cow manure doses

Table 9. Effect of cow manure dosage on the content of chlorophyll, carotenoids and anthocyanin of the leaves of dewa leaf

\begin{tabular}{lllll}
\hline $\begin{array}{l}\text { Treatm } \\
\text { ent }\end{array}$ & $\begin{array}{l}\text { Chloroph } \\
\text { yll a } \\
(\mathrm{mg} / \mathrm{g})\end{array}$ & $\begin{array}{l}\text { Chloroph } \\
\text { yll b } \\
(\mathrm{mg} / \mathrm{g})\end{array}$ & $\begin{array}{l}\text { Caroten } \\
\text { oids } \\
(\mathrm{mg} / \mathrm{g})\end{array}$ & $\begin{array}{l}\text { Anthocy } \\
\text { anin } \\
(\mathrm{mg} / 100 \\
\mathrm{g})\end{array}$ \\
\hline Control & 0.384 & 0.141 & 0.121 & 0.000 \\
S500 & 0.464 & 0.162 & 0.904 & 0.003 \\
S1000 & 0.468 & 0.188 & 0.138 & 0.023 \\
\hline F Test & $0.62 \mathrm{~ns}$ & $0.27 \mathrm{~ns}$ & $0.36 \mathrm{~ns}$ & $0.28 \mathrm{~ns}$ \\
CoD & & & & $11.213^{\wedge}$ \\
(\%) & 13.331 & 11.638 & $17.111^{\wedge}$ & 11.30 \\
\hline
\end{tabular}

Remarks: Figures on the same column followed by the same letter show no significantly different results based DMRT at the level of $\alpha=$ $5 \%$ * $^{*}$ Significantly different at the level of $\alpha=5 \%$, ns = not significant, $\mathrm{COD}=$ coefficient of diversity, WAT $=$ weeks after treatment ${ }^{\wedge}=$ transformation $\sqrt{(\mathrm{x}+1)}$.

\section{DISCUSSION}

The treatment of cow manure with a dose of S500 and S1000 did not significantly affect the growth and content of bioactive compounds of the dewa leaf compared to those without cow manure. Addition of fertilizers to the soil, both organic and inorganic fertilizers, should be able to increase the growth and production of plant bioactive compounds as well as previous studies conducted by 
Utami and Hartutiningsih (1998), Moraliza (2004) and Tripatmasari (2008).

Utami and Hartutiningsih (1998) reported that with the use of organic fertilizers as a growing medium on the leaves of dewa leaf with a ratio of 1: 1: 1, it yielded better results of $34.90 \mathrm{~g}$ dry weight. Moraliza (2004) found that cow dung fertilizer dose of $50 \mathrm{~g} /$ plant significantly affected plant height, leaf length, wet weight of the leaves of dewa leaf. Tripatmasari (2008) study concluded that the treatment of cow manure at a dose of 20 tons/ha has been able to increase growth and levels of bioactive compounds of dewa leaf and significantly different from treatments without fertilizer, but cow manure treatment (20 tons/ha) $+\mathrm{NPK}(\mathrm{N}=300 \mathrm{~kg} / \mathrm{ha}, \mathrm{SP} 36=100 \mathrm{~kg} / \mathrm{ha}, \mathrm{KCl}$ $=50 \mathrm{~kg} / \mathrm{ha}$ ) is the best treatment.

This is in line with the opinion of Soepardi (1983) which states that animal manure contains organic matter and micro nutrients which function to maintain and increase soil fertility needed by plants. Bockman and Kaarstad (1999) add that manure is very helpful in improving soil properties such as soil permeability, soil porosity, soil structure, water holding capacity and soil exchange capacity.

The incompatibility of results obtained in this experiment with previous studies such as those cited above is allegedly due to caterpillar pest attacks. This can be seen in the irregularities of the data obtained, including the increase in plant growth (height, number of leaves, leaf width, leaf length) per week which is worth 0 and even negative. The attack of caterpillar pests that ate plant leaves made plant height, number of leaves, leaf length and leaf width in the following week's measurements lower than the previous week. This happened because the sample used in the previous week was different from the sample in the following week because the caterpillar had eaten it.

Caterpillar attacks have disrupted the growth of the dewa leaf at the age of 2 WAT until harvested early. Experiments carried out organically or without providing other inputs from outside in addition to the treatment given make plants vulnerable to pest disorders. Caterpillars attack plants by eating leaves until they only leave the stalks. In addition, the placement of experimental units in shaded and open areas is also thought to play a role in increasing the attractiveness of caterpillars to the leaves of the plant because it is wider, crisper, brighter and smoother, so it is thought to be more delicious when eaten fresh. Taiz and Zeiger (1991) state that thinning of leaves at low light intensity is caused by a reduction in the palisade layer and mesophyll cells. Leaves planted at high light intensity (without shade) produce hard leaves.

The results of the observations on the variables of chlorophyll a, chlorophyll b, carotenoids and anthocyanin also influenced the growth of dewa leaf which were not optimum Vickery and Vickery (1981) stated that secondary metabolites derived from primary metabolites and primary metabolites obtained from photosynthesis. Taiz and Zeiger (1991) state that photosynthesis takes place in leaves and photosynthesis (photosynthate) stored in sinking organs such as stems, leaves, roots, and fruit. The content of chlorophyll $a$, chlorophyll $b$, carotenoids and anthocyanins which are not significantly different from this treatment is thought to be due to disruption of the primary metabolic process and loss of photosynthates (primary metabolites) stored in stems and leaves which should be precursors to the formation of secondary metabolites. Tripatmasari (2008) study concluded that the interaction between cow manure and harvest time significantly increased leaf wet weight and total leaf anthocyanin production. The treatment of cow manure ( 20 tons/ha) and 4 months of harvest significantly increased the highest leaf wet weight $(38.83 \mathrm{~g})$ and increased the highest total anthocyanin leaf production (13.41 $\mathrm{mg} /$ plant). In this experiment the leaves of dewa leaf were only 8 weeks old ( 2 months).

\section{CONCLUSION}

Fertilizing with cow manure in this experiment is still not able to increase the growth of canopies, tubers and the content of the bioactive compounds of dewa leaf properly. The high rate of caterpillar attacks since the second week has disrupted growth and the production of bioactive compounds from the leaves of dewa leaf.

\section{REFERENCES}

Bockman OC, Kaarstad O (1999). Agriculture Fertilizers and The Environment. Cambridge. United Kingdom: The University Press. $294 \mathrm{p}$.

Fuadzy H, Marina R (2012). Potential of Dewa Leaves (Gyanura pseudochina [L.] DC.) As Aedes Aegypti (Linn.) Larvacides. Aspirator 4(1): 7-13.

Gati E, Purnamaningsih R (1994). Micropropagation of deity leaves through in vitro culture. Proceedings of the Symposium on Research in Natural Medicine VIII. Spice and Medicinal Plant Research Institute. Vol VIII: pp. 58-61. 
Hernani A (2008). Effect of cow manure dosage on growth of organic Java chili (Piper reftrofractum Vahl) seedlings [thesis]. Bogor (ID): Bogor Agricultural University.

Lingga P (1998). Instructions for Using Fertilizers. Jakarta (ID): Penebar Swadaya. $163 \mathrm{p}$.

Mahendra B (2005). 13 Types of effective medicinal plants. Jakarta (ID): Penebar Swadaya.

Marsono SP (2001). Root Fertilizer, Types and Applications. Jakarta (ID): Penebar Swadaya. $96 \mathrm{p}$.

Moraliza I (2004). The effect of casting and cow manure on the production of lleaves of Dewa Leaf [thesis]. Bogor: Department of Agriculture, Faculty of Agriculture, Bogor Agricultural University.

Nakbanpote W, Natthawoot P, Kannika S, Orapan M, Wattchara N (2010). Advances in Doctoral Research Research: A Case Study of Gynura pseudochina (L.) DC. Mahasarakham University, Thailand.

Novayanti D (2012). Effect of dewa leaf extract (Gyanura pseudochina [L.] DC.) On bleeding and coagulation time in white rats (Rattus norvegicus $L$ ) as one of the alternative sources of learning biology on the circulatory system class XI semester I Madrasah Aliyah [essay]. Yogyakarta (ID): Sunan Kalijaga State Islamic University.

Ratnaningsih I, Dyatmiko C, Santa IGP (1985). Preliminary phytochemical study of Gynura procumbens Back. Purwokerto: Proceedings of the first seminar on the cultivation of medicinal plants October 17-18 1985. 8 p.

Santoso B (1997). Efficacy of pre-grown herbicides at various doses of cow manure on the growth and yield of rhino ginger (Zingiber officinale Rosc) [thesis]. Bogor (ID): Bogor Agricultural University.

Soepardi G (1983). Nature and Characteristics of Soil. Bogor (ID): Land Department. Faculty of Agriculture, Bogor Agricultural University. 591.

Soetarno S, Suganda AG, Sugihartina G, Sukrasno H (2000). Flavonoids and phenolic acids from the leaves of dewa leaf (Gynura procumbens). News of Indonesian Medicinal Plants. 6: 6-7.

Sugito, Y, Nuraini Y, Nihayati E (1995). Organic Farming System. Faculty of Agriculture. Brawijaya University. Poor. $84 \mathrm{p}$.

Suharmiati, Maryani H (2003). Benefits and Benefits of Dewa Leaves and Sambung Nyawa. Jakarta (ID): Agromedia Library. 49 p.
Suriadikarta DA, Simanungkalit RDM (2006). Organic Fertilizers and Biofertilizers. Simanungkalit RDM, Suriadikarta DA, Saraswati R, Setyorini D, Hartatik W, editor. Bogor (ID): Center for Agricultural Research and Development of Agricultural Land Resources.

Sutanto R (2002). Application of Organic Agriculture: Correctional and Development. Yogyakarta (ID): Kanisius. 219 p.

Sutedjo, MM (1994). Fertilizer and Fertilization Method. Rineka Putra. Jakarta (ID): 176 things.

Syukur C, Hermani (2001). Commercial Medicinal Cultivation. Jakarta (ID): Penebar Swadaya.

Taiz L, Zeiger E (2002). Plant Physiology. Sinauer Associates

Taufiq A, Kuntyastuti H, Prahoro C, Wardani T (2006). Provision of lime and manure on soybeans on acidic dry land. Increased Production of Pulses and Tubes Supporting Food Independence. Agricultural Research and Development Agency. Food Crop Research and Development Center. Bogor. Thing 214-228.

Tripatmasari $M$ (2008). Effect of fertilization and harvesting time on anthocyanin production of leaves and quercetin tubers of the leaves of dewa leaf (Gynura pseudochina (L.) Dc). [Thesis] not published. Postgraduate School. Agricultural Institute. Bogor.

Utami NW, Hartutiningsih B (1998). Productivity of Gynura procumbens (LM). on various growing media and shade levels. Bogor: Botanical Research and Development. Research Center for Biology-LIPI.

Vickery ML, Vickery B (1981) Secondary Plant Metabolism. London and Basingstoke (UK): The Mc Millan Pres Ltd.

Wanohadi E, Palupi S (2000). Comparison of microscopic and macroscopic dewa leaf powder (Gynura procumbens var. Macrophylla) with life-sustaining (Gynura procumbens (Lour) Merr.) News of Indonesian medicinal plants. 6: 4-5.

Windono T, Jenie UA (2012). Exploration and isolation of the bioactive content of leaves and tubers of dewa leaf Gyanura pseudochina [L.] DC.) [Thesis]. Yogyakarta (ID): Gajah Mada University.

Yuliarti N (2009). 1001 Ways to Produce Organic Fertilizers. Yogyakarta (ID): Lily Publisher. 70 things. 